\title{
$835 \mathrm{MHz}$ 및 $1,800 \mathrm{MHz}$ 대역에서 인체의 전기적 특성을 가지는 한국인 손 모양의 팬텀 제작
}

\section{Manufacturing of a Korean Hand Phantom with Human Electrical Properties at $835 \mathrm{MHz}$ and $1,800 \mathrm{MHz}$ Bands}

\author{
최 동 근 ${ }^{* \star * *} \cdot$ 김 윤 명** $\cdot$ 최 재 훈*** \\ Donggeun Choi***** Yoonmyoung Gimm** J Jaehoon Choi*** \\ 요 약
}

휴대전화의 이용이 증가하면서, 손에 미치는 전자파의 영향에 대한 관심이 증가하고 있다. IEC TC106에서도 휴대전화의 전자파 인체 노출량 평가 방법 표준에 손 영향을 반영하기 위하여 국제적인 교류 연구가 활발하게 진행되고 있다. 현재 상용화된 손 팬텀은 평균 서양인 손을 이용하고 있을 뿐만 아니라, 한 가지 형태의 파지(把 持)만 가능하기 때문에, SAR 측정 결과에 대한 분석에 제한이 많은 실정이다. 손의 영향을 제대로 분석하기 위 해서는 다양한 형태의 파지가 가능한 손 팬텀이 필요하다. 또한, 국내 환경에 맞는 손 팬텀의 개발이 필수적이 다. 본 논문에서는 다양한 형태의 파지가 가능한 $835 \mathrm{MHz}$ 대역과 $1,800 \mathrm{MHz}$ 대역의 한국인의 젤리형 손 팬텀을 제작하였다. 제작된 손 팬텀의 전기적 특성은 비유전율과 도전율이 $\mathrm{CTIA}$ (미국이동통신산업협회) 권고 기준 값 의 $\pm 10 \%$ 이내로서, CTIA에서 제시하는 오차 기준 $( \pm 20 \%)$ 보다 더 우수한 특성을 나타냈다. 또한, 손 팬텀의 $3 \mathrm{D} \mathrm{CAD}$ (3차원 컴퓨터 이용 설계) 파일을 개발하여 손에 의한 $\mathrm{SAR}$ 영향 분석을 위한 시뮬레이션에서 활용할 수 있도록 하였다. 본 연구를 통해 제작된 젤리형 손 팬텀과 $3 \mathrm{D}$ 파일은 휴대 전화의 손 영향에 대한 연구에 유용하게 이용될 수 있을 것으로 본다.

\begin{abstract}
Interest of the hand effect on the electromagnetic wave are internationally increasing with the increase of the use of the mobile phone. IEC TC106(International Electrotechnical Commission, Technical Committee 106) promotes international research exchange program in order to reflect the effect of human hands in the standard assessment method of human exposure dosimetry by the electromagnetic wave of mobile phones. Since current commercialized hand phantom is manufactured by taking into account the average size of westerners and provides only one grip posture, it imposes many restrictions on the accurate SAR measurement. Therefore, the development of proper hand phantom accounting for domestic situation and various grip posture capability is essential in order to analyze the accurate effect of human hand on the exposure estimation. In this paper, a jelly hand phantom suitable for Korean was manufactured with various grip posture capability at $835 \mathrm{MHz}$ and $1,800 \mathrm{MHz}$ bands. Although the tolerances of permittivity and conductivity of the manufactured hand phantom are with $\pm 10 \%$ each, it was much less than CTIA(Cellular Teleco-
\end{abstract}

\footnotetext{
「본 연구는 방송통신위원회의 전파방송위성원천기술개발사업의 연구 결과로 수행되었음(KCA-2011-11911-01109).」

*국립전파연구원 전파환경안전과(EMF Environment Safety Division, National Radio Research Agency)

**단국대학교 전자전기공학과(Department of Electronics and Electrical Engineering, Dankook University)

***한양대학교 전자컴퓨터통신공학과(Department of Electronic \& Computer Engineering, Hanyang University)

- Manuscript received February 26, 2013 ; Revised April 25, 2013 ; Accepted April 30, 2013. (ID No. 20130226-032)

- Corresponding Author : Jaehoon Choi (e-mail : choijh@hanyang.ac.kr)
} 
mmunication Industry Association) tolerance of $\pm 20 \%$ at both bands. Its 3D CAD(3 Dimensional Computer Aided Design) file which was developed can be utilized for the simulation of human hand effect on SAR measurement of mobile phones. The findings in this study can be utilized for the analysis of human hand effect on SAR measurement of a mobile phone.

Key words : SAR, Hand Effect, Hand Phantom, IEC TC106, CTIA

\section{I. 서 론}

2011년 $\mathrm{WHO}$ (세계보건기구)가 휴대전화에서 발 생하는 전자파를 발암 가능 물질 $(2 \mathrm{~B}$ 등급)로 지정함 에 따라 일반 국민들이 전자파로부터 인체 영향에 대한 의구심이 날로 증가하고 있다. 우리나라뿐만 아니라 세계 각국에서는 이를 해소하기 위하여 보다 정확한 전자파 인체 영향 평가 및 분석 연구에 많은 노력을 하고 있다. 휴대전화를 얼굴에 댈 때는 손으 로 잡으면서 사용하기 때문에, 휴대전화의 전자파 인체 영향을 제대로 검증하고 평가하기 위해서는 인 체와 동일한 전기적 특성을 갖는 손을 모사하는 팬 텀이 필요하다 ${ }^{[1]-[5]}$.

최근 IEC, IEEE, CENELEC 등에서 기존의 SAR 측정 방법 표준에서는 휴대전화를 파지(把持)하는 손가락 및 손 모양이 개인적인 성향 및 특성에 따라 매우 다양하고 복잡하여 손 팬텀을 구현하기 어렵다 고 언급하고 있으며, 향후 필요할 경우에 손 팬텀의 표준을 권고하겠다고 하였다 ${ }^{[1] \sim[3]}$. 현재 IEC TC106 에서는 휴대전화의 SAR 측정 방법 표준 개발에 손 영향을 반영하기 위한 프로젝트 팀을 운영하고 있으 며, 각국의 전문가들로 구성된 연구반을 구성하여 손에 의한 SAR 영향 분석을 위하여 지정 시험기관 간의 비교 SAR 측정을 진행하고 있다 ${ }^{[3]}$. 하지만, 비 교 SAR 측정은 CTIA에서 제시하고 있는 외국인 손 크기와 한 가지 파지만 가능한 손 팬텀을 사용하여 ${ }^{[4]}$ 동양의 환경을 충분히 반영하지 못했을 뿐만 아니 라, SAR 측정 운용자에 따라 손 팬텀의 거치 방법이 달라서 신뢰성이 있는 결과를 얻지 못하고 있는 실 정이다. 또한, 기존의 손 영향에 대한 연구 결과들은 손에 의한 영향으로 휴대전화의 안테나 매칭이 틀어 져 SAR 값이 낮게 나온다는 결과가 대부분이어서 ${ }^{[5]}$ [9] 측정 방법 표준에 반영이 되지 않았다. 하지만 최근에 실시된 각국의 비교 SAR 측정 결과에서 일 부 데이터가 SAR 값이 높게 나타나는 결과가 있어서
IEC TC106에서는 SAR 측정 방법 표준에 손의 영향 을 반영하기로 결정하였다 ${ }^{[3]}$.

그러므로 정확한 전자파 영향 분석 연구를 위해 서는 국내 환경에 맞는 동양인 손과의 비교 연구와 다양한 파지가 가능한 손 팬텀 개발이 필요하다 ${ }^{6],[10]}$.

본 논문에서는 $835 \mathrm{MHz}$ 및 $1,800 \mathrm{MHz}$ 대역에서 CTIA가 제시하는 사람 손과 동일한 전기적 특성을 가지는 한국인의 젤리형 손 팬텀을 제작하는 새로운 방법을 제시하였다. 그리고 제작된 손 팬텀의 전기 적 특성을 확인하기 위하여 유전율 측정기를 이용하 여 전기적 특성을 측정하였다. 또한, SAR 수치 해석 을 위한 시뮬레이션 툴(simulation tool)에서 사용이 가능한 손 팬텀의 $3 \mathrm{D} \mathrm{CAD}$ 파일을 개발하였다.

\section{II. 팬텀과 3D CAD 파일의 규격, 재료 및 제작}

제안한 손 팬텀은 국내 성인 남성 30 명의 오른손 크기와 한 표본 당 20 개의 특징 점을 조사한 결과를 평균하여 기준이 되는 국내 성인의 우측 손을 선정 하여 제작하였다. 그림 1 은 손의 크기를 확인하기

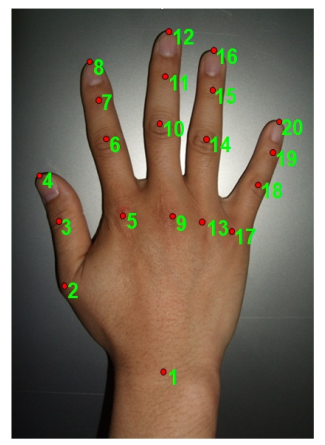

(a) 오른손등 번호

(a) Numbers indicating the positions on the back of the right hand

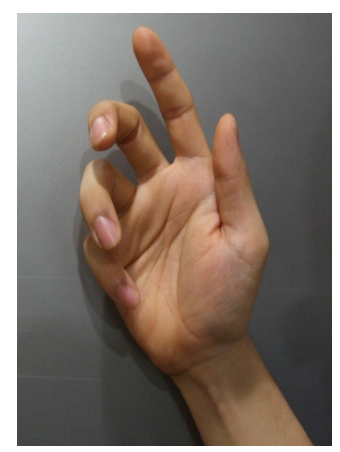

(b) 휴대전화 파지 모습

(b) Grip view of mobile phone
그림 1. 오른손등 번호 및 모형

Fig. 1. Numbers indicating the positions on the back of the right hand and grip view. 
위해 손등 번호 및 파지 모형을 보여주고 있으며, 표 1 은 성인 남성의 오른손 크기를 나타낸다. 손 팬텀 은 $835 \mathrm{MHz}$ 및 $1,800 \mathrm{MHz}$ 주파수 대역에서 사용 가 능하도록 각 대역마다 1 개씩을 제작하였다. 그리고 바(bar) 형태 등의 다양한 크기의 휴대전화를 파지할 수 있도록 엄지 손가락을 $180^{\circ}$ 회전할 수 있도록 하 였으며, 검지 손가락은 좌, 우 방향으로 각 $1 \mathrm{~cm}$ 씩 움직일 수 있도록 제작하였다.

표 1 에서 제시하는 값들과 가장 근접한 크기를 가 지는 국내 성인 남성의 오른손을 선택한 후, 바 타입 등의 휴대전화를 파지할 수 있는 형태를 유지하면서 $3 \mathrm{D}$ 스캐너 ${ }^{[1]}$ 를 사용하여 $360^{\circ}$ 도 회전하면서 스캔 작업을 수행하였다. 그리고 손 팬텀 제작을 위한 성

표 1. 국내 성인 남성 30 명의 오른손등 번호 간의 거 리 및 손등 번호의 해당 손가락 둘레의 평균 측정치

Table 1. Average values of distance between right hand back numbers and average values of finger girths of corresponding the back numbers of 30 Korean male hands.

\begin{tabular}{|c|c|c|c|}
\hline 손등의 번호 & $\begin{array}{c}\text { 번호간 거리 } \\
(\mathrm{mm})\end{array}$ & $\begin{array}{c}\text { 손등의 } \\
\text { 번호 }\end{array}$ & $\begin{array}{c}\text { 해당 손가락 } \\
\text { 둘레 }(\mathrm{mm})\end{array}$ \\
\hline $1 \sim 2$ & 83 & 1 & 176 \\
\hline $2 \sim 3$ & 40 & 2 & 77 \\
\hline $3 \sim 4$ & 32 & 3 & 70 \\
\hline $1 \sim 5$ & 95 & 5 & 71 \\
\hline $5 \sim 6$ & 49 & 6 & 64 \\
\hline $6 \sim 7$ & 26 & 7 & 54 \\
\hline $7 \sim 8$ & 22 & 9 & 70 \\
\hline $1 \sim 9$ & 90 & 10 & 67 \\
\hline $9 \sim 10$ & 56 & 11 & 55 \\
\hline $10 \sim 11$ & 30 & 13 & 65 \\
\hline $11 \sim 12$ & 26 & 14 & 64 \\
\hline $1 \sim 13$ & 90 & 15 & 50 \\
\hline $13 \sim 14$ & 50 & 17 & 70 \\
\hline $14 \sim 15$ & 29 & 18 & 53 \\
\hline $15 \sim 16$ & 24 & 19 & 45 \\
\hline $1 \sim 17$ & 92 & & \\
\hline $17 \sim 18$ & 34 & & \\
\hline $18 \sim 19$ & 22 & & \\
\hline $19 \sim 20$ & 20 & & \\
\hline & & & \\
\hline
\end{tabular}

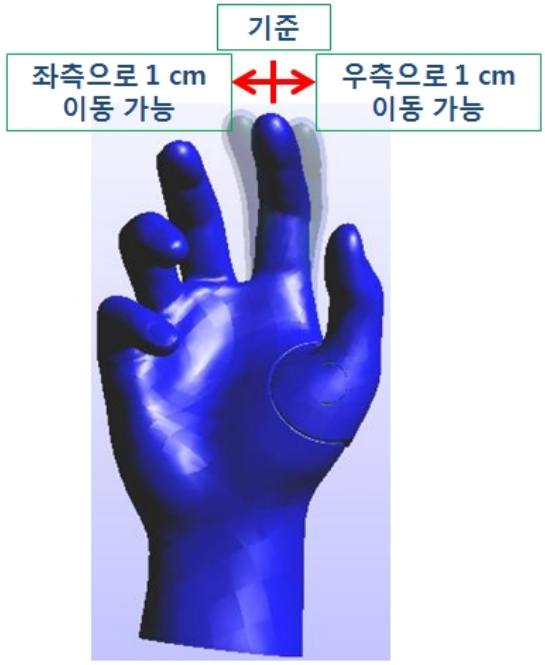

그림 2. 제작된 손 팬텀의 $3 \mathrm{D} \mathrm{CAD} \mathrm{파일}$

Fig. 2. 3D CAD file of fabricated hand phantom.

형 틀 제조와 전자파 영향 분석을 위한 시뮬레이션 용 모델링에 사용할 3D CAD 파일을 만들기 위하여 편집 소프트웨어를 사용하여 스캔한 손의 3차원 데 이터를 각 프레임별로 하나의 완성된 3D 모델로 완 성하였다. 제작한 손 모양의 $3 \mathrm{D} \mathrm{CAD}$ 파일은 $\mathrm{SAR}$ 수치 해석용 상용 시뮬레이션 툴에서 모델링이 가능 하도록 제작하였으며, 손 팬텀의 성형 틀 제조에도 사용하였다. 그리고 엄지 손가락은 $180^{\circ}$ 도 회전할 수 있게 제작하여 다양한 크기의 휴대전화를 파지할 수 있도록 하였으며, 검지 손가락은 가운데 위치를 중심으로 좌우로 각 $1 \mathrm{~cm}$ 씩 이동 가능하도록 개발하 였다(그림 2) ${ }^{[12]}$.

손 팬텀 제작은 실물 크기대로 스캔한 표준 남성 의 오른손 $3 \mathrm{D} \mathrm{CAD}$ 데이터를 이용하여 수치 제어 (NC: Numerical Control) 기계로 손 모양을 가공하였 고, 적층 방법을 사용하여 오른손 성형 틀을 제작하 였다. 제작된 팬텀 성형 틀의 재질은 저 유전율 및 저 손실 재료를 선정하여 제작하였으며(비(比) 유전 율 5 이하, 손실 탄젠트 0.05 이하), 껍질(shell) 두께 는 $2 \mathrm{~mm}$ 로 하였다.

성형 틀 속에 충전(充壃)시키는 팬텀 재질로는 액 체형, 젤리형, 고체형 팬텀 등이 있으나, 본 논문에 서는 손의 형태를 유지할 수 있고, 손가락을 움직일 수 있도록 젤리 형태로 제작하였다. 액체형 팬텀은 용량 및 부피가 커서 보관이 어려우며, 밀봉하여 보 
표 2. $835 \mathrm{MHz}$ 및 $1,800 \mathrm{MHz}$ 대역을 위한 젤리형 손 팬텀의 물질 및 질량 구성비

Table 2. Composition of materials used for jelly hand phantom at $835 \mathrm{MHz}$ and $1,800 \mathrm{MHz}$ bands.

\begin{tabular}{|c|c|c|}
\hline \multirow{2}{*}{ 성 분 } & \multicolumn{2}{|c|}{ 질량 구성비(\%) } \\
\cline { 2 - 3 } & $835 \mathrm{MHz}$ 대역 & $1,800 \mathrm{MHz}$ 대역 \\
\hline 증류수 & 36.54 & 47.42 \\
\hline 글리세롤 & 53.48 & 38.15 \\
\hline 소금 & 0.89 & 0 \\
\hline 폴리에틸렌 가루 & 3.74 & 10.31 \\
\hline 한천 & 5.35 & 4.12 \\
\hline 목표 비유전율 & $30.3 \pm 20 \%$ & $27 \pm 20 \%$ \\
\hline $\begin{array}{c}\text { 목표 도전율 } \\
\text { [S/m] }\end{array}$ & $0.29 \pm 20 \%$ & $0.99 \pm 20 \%$ \\
\hline
\end{tabular}

존하지 않으면 재질의 전기적인 특성이 쉽게 변하는 단점이 있기 때문에 ${ }^{[13]}$ 새롭게 제안된 젤리형 손 팬 텀을 이용하면 이를 보완할 수 있다 ${ }^{[14]}$.

젤리 팬텀 제조에 사용되는 재료는 시중에서 쉽 게 구할 수 있는 글리세롤(glycerol), 증류수(deionized water), 소금 $(\mathrm{NaCl})$, 한천(agar), 폴리에 틸렌 가루(polyethylene powder) 등을 사용하였다. 여기서, 증류수와 폴리에 틸렌 가루는 양에 따라 비(比)유전율을 조절 할 수 있으며, 소금은 도전율을 조절할 수 있다. 또 한, 글리세롤은 팬텀을 장기간 사용할 수 있도록 방 부제 역할을 하며, 젤리 형태로 모양을 유지한다. 한 천은 액체 형태의 팬텀 재료들을 고형화 시킨다 ${ }^{[15]}$.

표 2에서는 $835 \mathrm{MHz}$ 와 $1,800 \mathrm{MHz}$ 대역에서 요구 되는 손 팬텀의 전기적 특성을 구현하기 위한 물질 들과 그 구성비를 제시하였다 ${ }^{[16]}$.

젤리형 손 팬텀의 제조는 목표 유전율과 도전율 을 만족하도록 재료를 정확히 조성하여야 한다. 또 한 혼합과정에서 공기가 유입되는 경우 원하는 전기 적 특성을 얻을 수 없게 된다. 젤리형 팬텀의 제조 방법은 아래와 같다 ${ }^{[14]}$.

1) 증류수, 글리세롤, 한천, 소금, 폴리에틸렌 가루 를 정밀 저울을 이용하여 표 2에서 제시하는 비율만큼 각각 측정하여 준비한다.

2) 먼저, 물에 소금을 녹이고, 제조한 소금물에 글 리세롤을 넣고 잘 섞어 준다.

3) 섞은 재료를 용기에 담아 가스레인지에 올려놓
고 약 20 분간 가열시킨다.

4) 아랫 부분이 타지 않도록 주걱으로 천천히 저 어준다.

5) 만들어진 혼합액을 교반기(stirrer) 용기에 담고 폴리에틸렌 가루를 체로 쳐서 넣는다.

6) 폴리에틸렌 가루가 골고루 섞이도록 거품기를 이용해 교반기 안의 재료들을 15 분간 저어 준다.

7) 제작한 손 모형의 실리콘 주형 안으로 공기가 들어가지 않도록 6 번에서 만든 재료를 천천히 넣는다.

8) 공기와 접촉하지 않도록 비닐 랩(wrap)을 씨우 고, 24시간 정도 상온에 식혀 굳힌다.

9) 제작된 젤리형 손 팬텀은 장기간 사용을 위하 여 냉장고에 보관한다.

\section{III. 팬텀 성능 측정}

제작된 젤리형 손 팬텀은 오른 손의 외형상 모양 을 그대로 재현하였고, 전기적인 특성은 표 2의 목 표값 범위 내에 들어가도록 제작하였다.

젤리형 손 팬텀 재질의 전기적인 특성을 측정하 기 위해서, 유전율 프로브 키트(dielectric probe kit, 모델: HP 85070E)와 회로망 분석기(network analyzer, 모델 : $\mathrm{HP} 8753 \mathrm{C}$ )를 사용하여 그림 3과 같이 측정 시 스템을 구성하였다.

측정 절차는 아래와 같다.

1) 회로망 분석기에 동축선 케이블을 연결한다.

2) 동축선 케이블 끝에 프로브를 연결한 후 공기

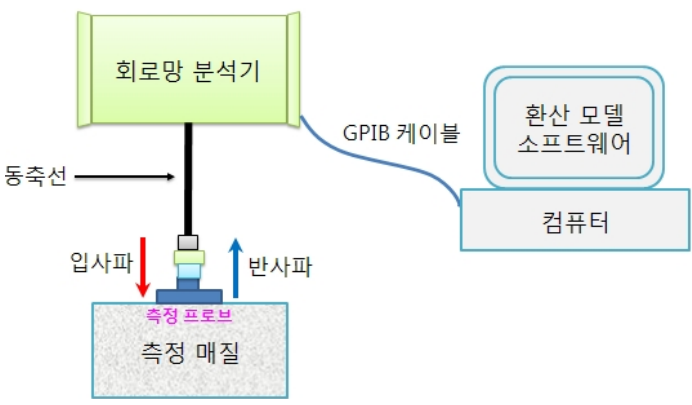

그림 3. 복소 유전율 측정 시스템 구성도

Fig. 3. Measurement system diagram of the complex dielectric constants. 

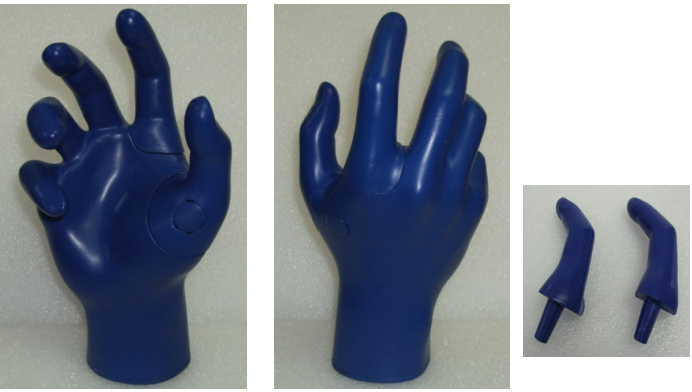

(a) 제작된 $835 \mathrm{MHz}$ 대역의 손 팬텀 및 검지 사진

(a) Fabricated jelly hand phantom and index finger for $835 \mathrm{MHz}$ band

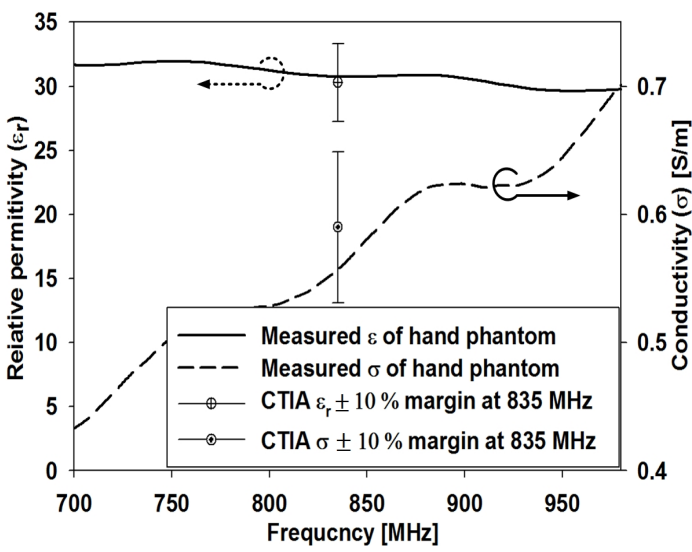

(b) $835 \mathrm{MHz}$ 대역의 전기적 특성

(b) Electrical properties at $835 \mathrm{MHz}$ band

그림 4. 측정된 $835 \mathrm{MHz}$ 젤리형 손 팬텀의 비유전 율과 도전율

Fig. 4. Measured dielectric constant $\left(\varepsilon_{r}\right)$ and conducti$\operatorname{vity}(\sigma)$ of $835 \mathrm{MHz}$ jelly hand phantom.

중에서 개방(open) 상태, 단락(short) 상태, 그리 고 증류수를 부하(load)로 한 상태에서 각각 유 전율 측정 시스템을 교정(calibration)한다.

3) 프로브 종단면을 측정 매질에 접촉한 후 전기 적 특성을 측정한다.

그림 4, 5는 제작된 $835 \mathrm{MHz}$ 및 $1,800 \mathrm{MHz}$ 대역 의 젤리형 손 팬텀의 실물과 비유전율 및 도전율의 전기적 특성 결과이다. CTIA에서 제시하는 손 팬텀 의 전기적 특성은 비유전율 및 도전율 기준과 대비 하여 $\pm 20 \%$ 의 오차 범위이내이어야 하지만 ${ }^{[4],[1],[17]}$, 개발한 젤리형 손 팬텀은 $835 \mathrm{MHz}\left(\varepsilon_{r}=30.3, \sigma=\right.$ $0.59)$ 및 $1,800 \mathrm{MHz}$ 대역 $\left(\varepsilon_{r}=27, \sigma=0.99\right)$ 에서 각각 $\pm 10 \%$ 이내의 오차 범위 이내에 들어가는 우수한
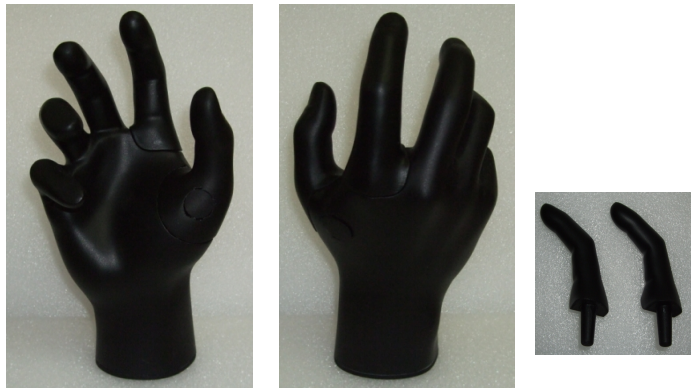

(a) 제작된 $1,800 \mathrm{MHz}$ 대역의 손 팬텀 및 검지 사진

(a) Fabricated jelly hand phantom and index finger for $1,800 \mathrm{MHz}$ band

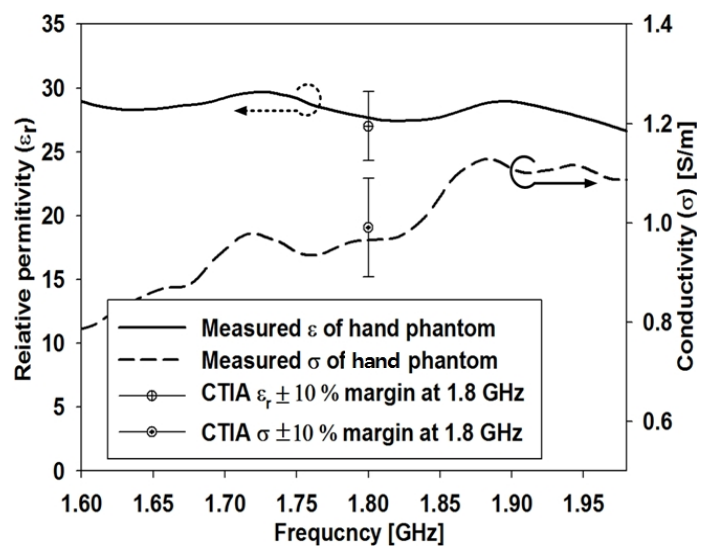

(b) $1,800 \mathrm{MHz}$ 대역의 전기적 특성 결과

(b) Electrical properties at $1,800 \mathrm{MHz}$ band

그림 5. 측정된 $1,800 \mathrm{MHz}$ 젤리형 손 팬텀의 비유전 율과 도전율

Fig. 5. Measured dielectric constant $\left(\varepsilon_{r}\right)$ and conductivi$\operatorname{ty}(\sigma)$ of $1,800 \mathrm{MHz}$ jelly hand phantom.

재질의 특성을 확보하였다. 여기서, $835 \mathrm{MHz}$ 대역은 $824 \sim 894 \mathrm{MHz}$ 이고, $1,800 \mathrm{MHz}$ 대역은 $1,750 \sim 1,870$ $\mathrm{MHz}$ 이다.

여러 연구 결과들에서 검지 손가락이 휴대전화 뒷면의 상하 및 좌우로 $1 \mathrm{~cm}$ 간격으로 터치하는 위 치 변화에 따라 TRP(총 방사 전력)값과 휴대전화의 안테나 반사 손실이 변하는 것으로 나타났다 ${ }^{[5],[12]}$. 본 연구를 통해 개발한 손 팬텀은 전자파의 다양한 영 향을 분석하는데 유용하게 활용될 것으로 사료된다.

\section{IV. 결 론}

CTIA에서 제시하는 $835 \mathrm{MHz}$ 및 $1,800 \mathrm{MHz}$ 대역 의 전기적 특성(비유전율과 도전율)을 구현할 수 있 
고 국내 성인 남성의 손 모양과 크기를 반영한 젤리 형 손 팬텀을 개발하였다. 젤리형 팬텀은 폴리에틸 렌 가루와 글리세롤과 소금 등을 이용하여 제작하였 으며, 제작된 팬텀의 측정 결과, CTIA에서 제시한 비유전율 $( \pm 10 \%)$ 과 도전율 $( \pm 10 \%)$ 을 만족하였다. 그리고 엄지와 검지 손가락을 움직이게 하여 다양한 크기의 휴대전화를 파지하고 터치할 수 있도록 하였 다. 또한, TRP, 안테나 반사손실, 방사패턴 등 전자 파 영향 분석을 위한 시뮬레이션 툴에 사용할 수 있 는 손 팬텀의 $3 \mathrm{D} \mathrm{CAD}$ 파일도 개발하였다. 개발된 손 팬텀은 향후 손에 의한 휴대전화의 SAR 영향 연 구에 널리 활용될 것으로 예상된다.

\section{참 고 문 헌}

[1] IEC, EN 62209-1, "Human exposure to radio frequency fields from hand-held and body-mounted wireless communication devices - Human models, instrumentation, and procedures - Part 1: Procedure to determine the specific absorption rate(SAR) for handheld devices used in close proximity of the ear (frequency range of $300 \mathrm{MHz}$ to $3 \mathrm{GHz}$ )", IEC(Feb. 2005), EN, Jul. 2006.

[2] IEEE Recommended Practice for Determining the Peak Spatial-Average Specific Absorption Rate (SAR) in the Human Head from Wireless Communications Devices: Measurement Techniques, IEEE Std. 1528TM, IEEE Standards Coordinating Committee 34, Dec. 2003.

[3] IEC 62209 MT HEMI international project, B. Derat, S. Gabriel, A. Faraone, Hand Effect Measurement Interlab Final Report, Aug. 2011.

[4] CTIA, "CTIA certification test plan for mobile station over the air performance", Method Meas. Radiated RF Power and Receiver Performance, Apr. 2009.

[5] 최명선, 장영호, 김윤명, 박한규, "손과 악세서리 에 의한 휴대폰 전자파의 인체 노출 특성", 한국 전자파학회논문지, 16(6), pp. 652-660, 2005년 6 월.

[6] C. H. Li, E. Ofli, N. Chavannes, and N. Kuster,
"Effect of hand phantom on mobile phone antenna performance", IEEE Trans. on Antennas and Propag., vol. 57, no. 9, pp. 2763-2770, Sep. 2009.

[7] N. A. Samsuri, J. A. Flint, "A study on the effect of loop-like jewellery items worn on human hand on Specific Absorption Rate(SAR) at 1,900 MHz", 2008 Loughborough Antennas \& Propag. Conference, vol. 3, no. 3, pp. 297-300, Mar. 2008.

[8] Liang-Cheng Kuo, Huey-Ru Chuang, "Design of a 900/1,800 MHz dual-band loop antenna mounted on a handset considering the human hand and head effects", Antennas and Propag. Society International Symposium, 2003. IEEE, vol. 3, no. 1, pp. 701-704, Jun. 2008 .

[9] Minh-Chau T. Huynh, Warren L. Stutzman, "A review of radiation effects on human operators of handheld radios", Microwave Journal, Jun. 2004.

[10] Chung-Huan Li, Mark Douglas, Erdem Ofli, Benoit Derat, and Niels Kuster, "User's hand effect on the specific absorption rate in the Head", AP-S URSI Symposium, pp. 141-144, Oct. 2009.

[11] EPIK, 3D scanner(미놀타사의 Vivid 9i).

[12] Dong-Geun Choi, Hak-Tae Oh, Sung-Tek Kahng, Do-Hwan Kwon, Sun-Goo Kim, and Chan-Ho Jeong, "Investigating the hand effect of the electromagnetic field from a mobile phone on the hearing aid", Bioelectromagnetics Society 32nd Annual Meeting (Seoul), Jun. 2010.

[13] Youn-Myoung Gimm, "General method of formulating the human tissue simulant liquid for SAR measurement", EMC'04 Sendai, vol. 2, no. 3B2-1, pp. 561-564, Jun. 2004.

[14] Y. Okano, A. Hase, I. Ida, and K. Ito, "A study on estimation of SAR in human head for electromagnetic energy exposure", APMC(Japan), Tech. Rep. TH2C-1, Dec. 1998.

[15] 이순용, 서원범, 권결, 최재훈, "MICS 대역과 ISM 대역에서 인체 전기적 상수를 갖는 준 고체형 플랫 팬텀 제작", 한국전자파학회논문지, 23(1), pp. 101-107, 2012년 1월.

[16] Y. Okano, K. Ito, I. Ida, and M. Takahashi, "The 
SAR evaluation method by a combination of thermographic experiments and biological tissue-equivalent phantoms", IEEE Trans. Microwave Theory Tech., vol. 48, no. 11, pp. 2094-2103, Nov. 2000.

최 동 근

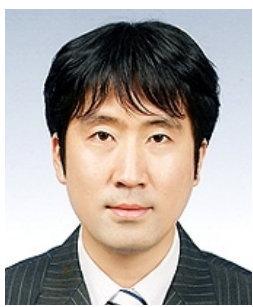

2003년 2월: 충북대학교 정보통신 공학과 (공학사)

2005년 2월: 충북대학교 정보통신 공학과 (공학석사)

2006년 7월 현재: 국립전파연구원 공업연구사

2010년 3월 현재: 한양대학교 전자 컴퓨터통신공학과 박사과정

[주 관심분야] SAR 평가 기술, 전자파 수치해석, 전자파 인체보호, 안테나 설계
[17] C. Gabriel, "Tissue equivalent material for hand phantoms", Phys. Medi. Biol., vol. 52, no. 14, pp. 42054210, Jul. 2007.
최 재 훈

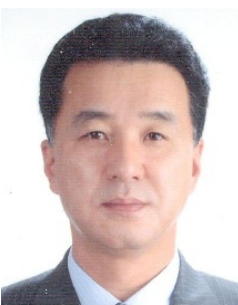

1980 년: 한양대학교 전자공학과 (공 학사)

1986년: 미국 Ohio State University 전기공학과 (공학석사)

1989년: 미국 Ohio State University 전기공학과 (공학박사)

1989년 1991년: 미국 Arizona State University 연구교수

1991년 1995년: 한국통신위성사업단 연구팀장 1995년 현재: 한양대학교 융합전자공학부 교수

[주 관심분야] 안테나 및 마이크로파 회로 설계, EMI/EMC
김 윤 명

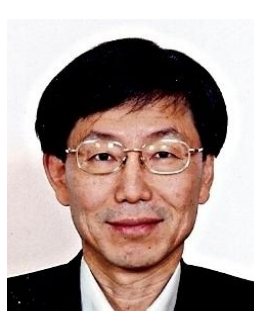

1975년 2월: 서울대학교 전자공학 과 (공학사)

1977년 2월: 한국과학원 전기 및 전 자공학과 (공학석사)

1990년 9월: 한국과학기술원 전기 및 전자공학과 (공학박사)

1977년 2월 1980년 2월: 금성정밀 공업주식회사(現 LIG 넥스원) 중앙연구소 연구원 1980년 3월 현재: 단국대학교 전자전기공학부 교수 2000년 6월 현재: (주)EMF Safety 대표이사 [주 관심분야] 전자파환경, $\mathrm{EMI/EMC,} \mathrm{전자계의} \mathrm{인체영향}$ 측정, 무선전력전달 등 